\title{
Study on the Eruption Timing of Permanent Teeth among Children Aged between Five and Ten Years Visiting Dental College in Mangalore India
}

\author{
Varshini Marimuthu, Pushparaja Shetty \\ Department of Oral and Maxillofacial Pathology and Oral Microbiology, AB Shetty Memorial Institute of Dental \\ Sciences (ABSMIDS), Nitte University, Deralakatte, Mangalore, India
}

SUMMARY

Teeth are biological markers of maturity, and their eruption into the oral cavity is an essential milestone in an individual's life. Multiple factors have been considered to play a role in the pattern of tooth eruption, including dental caries, fluorides and congenital conditions such as Down's syndrome.

The aim of the paper was to determine the time of eruption of permanent teeth amongst children aged between five and ten years, visiting the Dental College in Mangalore.

A survey was conducted among children aged between 5 to 10 years visiting A.B. Shetty Memorial Institute of Dental Sciences Deralakatte, Mangalore. Each child included in the study was screened by clinical examination for the erupted and erupting permanent teeth. A parent/guardian accompanying a child was interviewed and their data were recorded.

The study revealed that the first tooth to erupt was the left mandibular first molar, with a mean age of eruption at 6.4 years. A slight early eruption of teeth was noticed in the left side of the jaw compared to the right side in the present study.

The first permanent tooth to erupt in the oral cavity is the left mandibular first molar and there is a slight delay in the eruption of the maxillary lateral incisor in the study population.

Key words: eruption, permanent teeth, dentition

Corresponding author:

Pushparaja Shetty

e-mail: drpusti@yahoo.com 


\section{INTRODUCTION}

Teeth are an essential part of the dentofacial complex. They are "biological markers of maturity", and their eruption into the oral cavity is an important milestone in an individual's life (1). An eruption is considered as a tooth with any part of the crown visible in the oral cavity (2).

Primary and permanent teeth are the two types of dentition humans have. First permanent teeth appear around the age of 5 to 6 years. There is a greater variation in eruption time of permanent dentition compared to primary dentition (3).

Many studies were conducted on the pattern of the eruption for both deciduous and permanent dentition in the past years. Multiple systemic and local factors are involved in altering the pattern of eruption which includes nutrition, genetics, dental caries, fluorides, congenital conditions such as Down's syndrome, cleidocranial dysplasia $(1,4)$.

Better nutrition and health care for children were considered for the early puberty and earlier eruption of teeth in industrialized countries (5). Height and weight of the children were also found to influence eruption in children $(6,7)$. Social and economic status influencing nutrition and hygiene practice may indirectly alter and influence the eruption mechanism (8). Several studies have shown that teeth erupt earlier in girls than boys $(4,8,9)$.

To date, very few studies have been done on Indian population, and hence the study was conducted in an attempt to determine the time of eruption of permanent teeth amongst children aged 5 to 10 years, in Deralakatte Mangalore.

\section{AIMS}

The survey aimed to identify the eruption pattern of permanent teeth amongst children aged between five and ten years, visiting the Dental College in Mangalore, India. The objectives of the study were as follows:

1. To study the time of eruption of the first permanent tooth in the study population.

2. To identify the mean age of eruption of permanent teeth in the study population.

3. To study the sequence of eruption of permanent teeth in the study population.

4. To analyze the difference in the right and left quadrants of the jaw in the eruption sequence in the study population.

\section{EXAMINEES AND METHODS}

The survey was conducted among the children visiting at A.B. Shetty Memorial Institute of Dental Sciences, Mangalore, India. The sample size of the study group consisted of 100 children, aged from 5 to 10 years. The study was conducted between July 2017 and July 2018.

Inclusion criteria for the study were: subjects born from uncomplicated pregnancies and deliveries and subjects with parents of Indian origin, particularly of South Indian.

Exclusion criteria for the study were: subjects with any systemic diseases; subjects with a syndrome such as Downs syndrome, etc; subjects with cleft lip and palate; Subjects with genetic and/ hereditary disorders, and, finally, mentally and physically disabled children.

\section{Methodology}

A cross-sectional survey was conducted among the children aged 5 to 10 years in and around Deralakatte in Mangalore, India, who visited A.B. Shetty Memorial Institute of Dental Sciences. Each child included in the study was screened by clinical examination for erupting as well as already erupted permanent teeth, and an accompanying parent/ guardian was interviewed and data were recorded. The examination of teeth started from the maxillary right quadrant for the presence of permanent teeth followed by the maxillary left, mandibular left quadrant, and mandibular right quadrant. The number of permanent teeth erupted in each quadrant in the oral cavity of each child was recorded. A tooth with any of its parts emerged through the gingiva in the oral cavity was considered as erupted. The interview and clinical examination of each subject took about 8 to 10 minutes. The data was tabulated with their corresponding age.

Statistical analysis of the data collected was carried out using SPSS (IBM version) software. The mean and standard deviation of the timing of eruption of the maxillary (first molars, central incisors, lateral incisors) and mandibular (first molars, central incisors, lateral incisors, canines) teeth were estimated. An independent Student's t-test was done to analyze the difference in the eruption time of the teeth in the left and right quadrants of the maxilla and mandible, if any. The sequence of eruption of 
the teeth in children aged 5 to 10 years was also determined.

\section{RESULTS}

The study group consisted of 100 children between the age of 5 and 10 years. The mean age observed for eruption of permanent dentition is from 6.4 years. The first tooth to permanent tooth to erupt in the oral cavity in the study group was permanent left mandibular first molar. Other eruption sequence followed in the left side was maxillary permanent molar, mandibular central incisor, maxillary central incisor, mandibular lateral incisor, maxillary lateral incisor, maxillary first premolar, mandibular first premolar, mandibular canine (Table 1).

The first tooth to erupt in the right side was mandibular first molar with mean age of 6.44 years followed by the maxillary first molar, mandibular central incisor, maxillary central incisor, mandibular lateral incisor, maxillary lateral incisor, maxillary first premolar, mandibular canine and mandibular first premolar (Table 1).

A slight early eruption of teeth was noticed on the left side of the jaw, except for the mandibular canines. However, the differences were not statistically significant (Table 2).

In the maxillary arch, there was a slight delay in eruption of lateral incisors when compared to the standard age of eruption of lateral incisors (Figure 1).

However, eruption timings of mandibular teeth observed in the present study were similar to other surveys done in Dakshina Kannada and the standard age of eruption mentioned in the literature (Figure 2).

Table 1. Mean age of eruption of teeth in children aged 5-10 years (Deralakatte, Mangalore)

\begin{tabular}{l|c|c|l|c|c}
\hline \hline \multicolumn{1}{c|}{$\begin{array}{c}\text { Teeth on the } \\
\text { right side }\end{array}$} & $\begin{array}{c}\text { Mean } \\
\text { age in } \\
\text { years }\end{array}$ & $\begin{array}{c}\text { Standard } \\
\text { deviation }\end{array}$ & \multicolumn{1}{|c|}{$\begin{array}{c}\text { Teeth on the } \\
\text { left side }\end{array}$} & $\begin{array}{c}\text { Mean } \\
\text { age in } \\
\text { years }\end{array}$ & $\begin{array}{c}\text { Standard } \\
\text { deviation }\end{array}$ \\
\hline 16 (Maxillary molar) & 6.482 & 0.508 & 26 (Maxillary molar) & 6.448 & 0.506 \\
\hline 11 (Maxillary central incisor) & 7.1250 & 0.7188 & 21 (Maxillary central incisor) & 7.1333 & 0.6399 \\
\hline 12 (Maxillary lateral incisor) & 9.1875 & 0.9810 & 22 (Maxillary lateral incisor) & 9.1875 & 0.9810 \\
\hline 14 (Maxillary premolar) & 9.7778 & 0.4409 & 24 (Maxillary premolar) & 9.6364 & 0.5045 \\
\hline 46 (Mandibular molar) & 6.4412 & 0.5609 & 36 (Mandibular molar) & 6.4062 & 0.6148 \\
\hline 41 (Mandibular central incisor) & 6.5714 & 0.5976 & 31 (Mandibular central incisor) & 6.5238 & 0.6015 \\
\hline 42 (Mandibular lateral incisor) & 7.2353 & 0.6642 & 32 (Mandibular lateral incisor) & 7.2353 & 0.6642 \\
\hline 43 (Mandibular canine) & 9.7778 & 0.4409 & 33 (Mandibular canine) & 9.8750 & 0.3535 \\
\hline 44 (Mandibular first premolar) & 9.8571 & 0.3779 & 34 (Mandibular first premolar) & 9.8333 & 0.4082 \\
\hline \hline
\end{tabular}

Table 2. Independent samples' test between eruption time of teeth in the right and left quadrants

\begin{tabular}{|c|c|c|c|c|c|c|}
\hline & & \multirow[t]{2}{*}{$\mathrm{t}$} & \multirow[t]{2}{*}{ df } & \multirow[t]{2}{*}{$\begin{array}{c}\text { Sig. } \\
\text { (2-tailed) }\end{array}$} & \multicolumn{2}{|c|}{$\begin{array}{c}95 \% \text { Confidence } \\
\text { Interval } \\
\text { of the difference }\end{array}$} \\
\hline & & & & & Lower & Upper \\
\hline \multirow{2}{*}{ Variance } & Equal variances assumed & .002 & 12 & .998 & -1.61730 & 1.62048 \\
\hline & Equal variances not assumed & .002 & 11.990 & .998 & -1.61746 & 1.62063 \\
\hline
\end{tabular}




\section{COMPARISON OF ERUPTION TIMINGS OF MAXILLARY TEETH IN ' PRESENT STUDY WITH SIMILAR STUDY IN DAKSHINA KANNADA STANDARD}

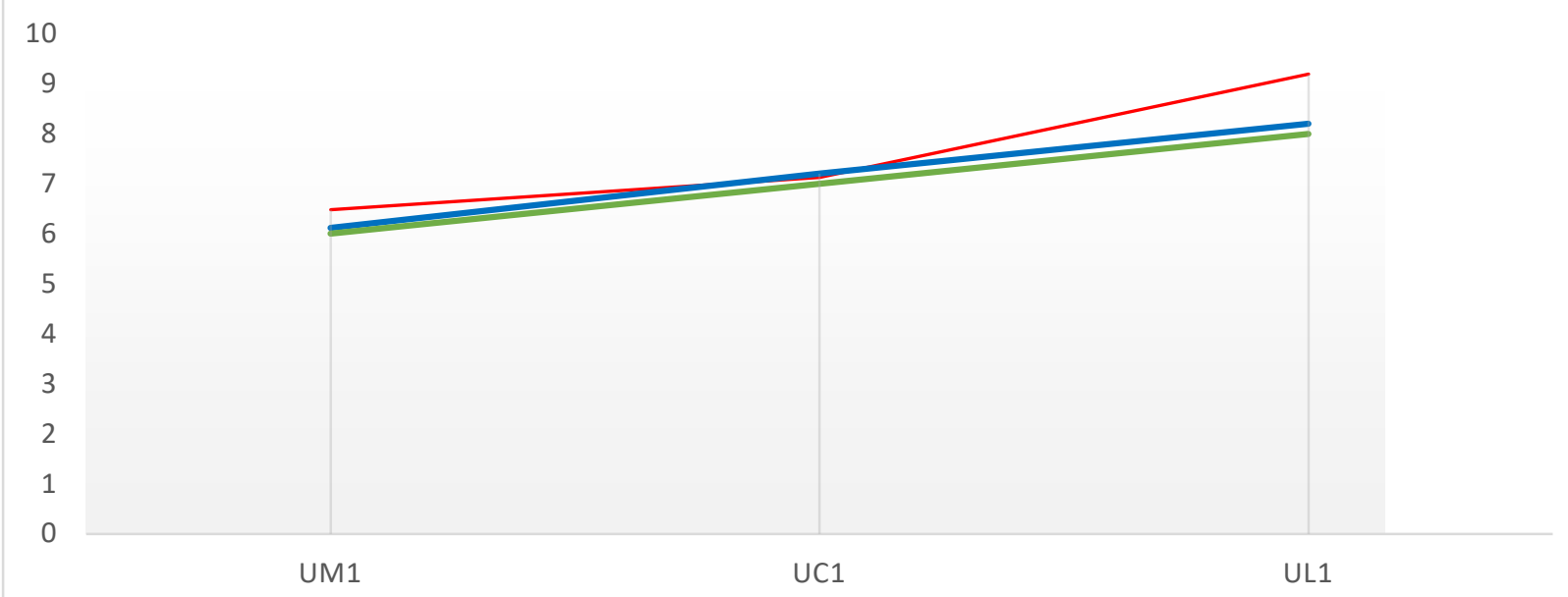

Figure 1. Comparison of eruption timings of maxillary teeth in the present study with a similar study in Dakshina Kannada and the standard age of eruption

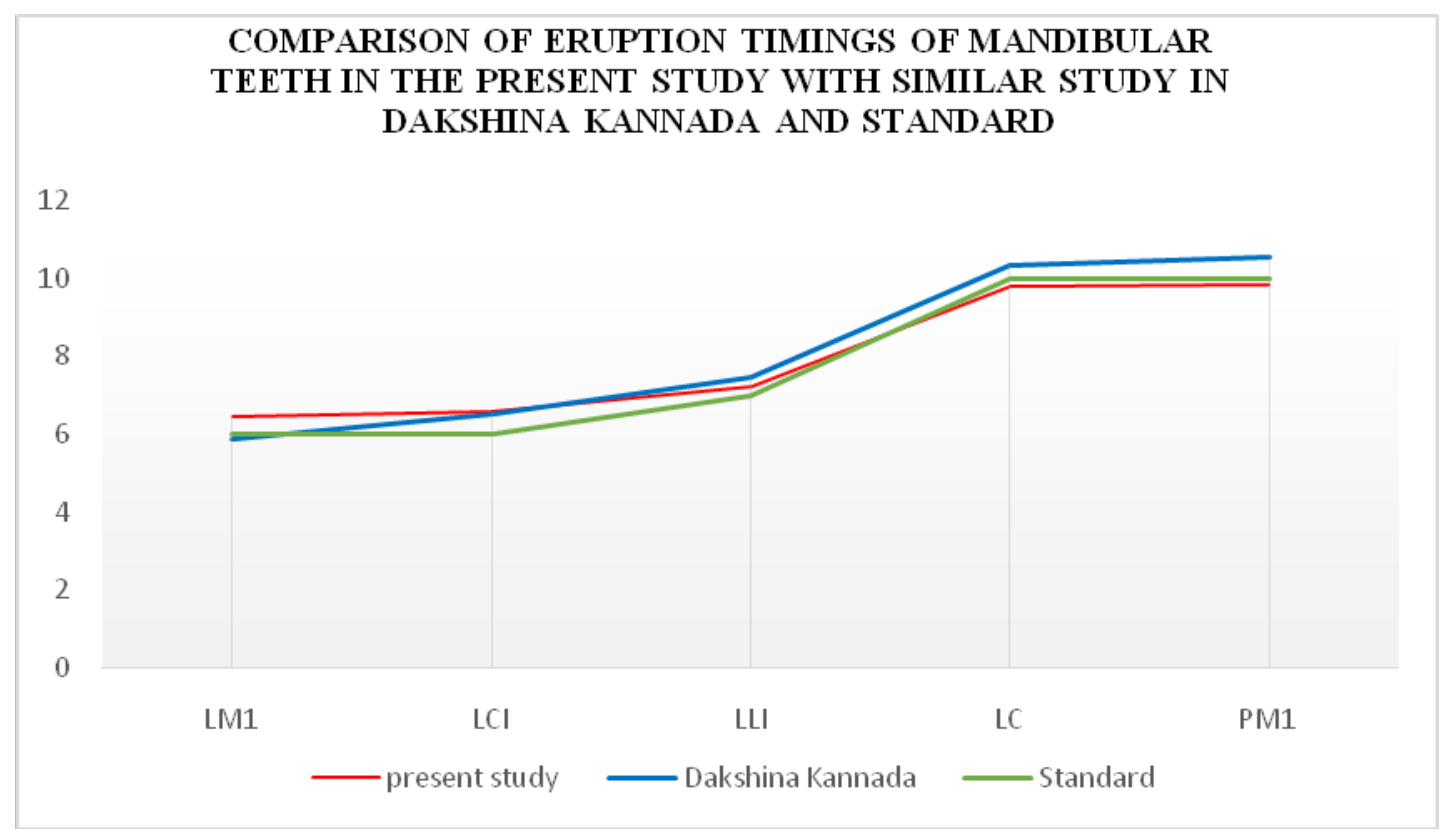

Figure 2. Comparison of eruption timings of mandibular teeth in the present study with a similar study in Dakshina Kannada and the standard age of eruption

\section{DISCUSSION}

Generally, there is a remarkable consistency in the eruption schedule of the human dentition that reflects a programmed eruption process. An example will be the term '6-year molars' used synonymously with the permanent first molars.

A study conducted on 5,007 randomly selected school children of Mysore, India between the ages of 5 to 14 years revealed that the eruption 
pattern was similar to most of the other studies across the world (10).

In an attempt to identify the eruption time of permanent teeth in Gowda community, girls were examined and the result showed that the mandibular central incisor and the second premolar erupted earlier than was reported in other studies on Indian population (11).

A study conducted on 1,008 subjects aged between 5-15 years of north-eastern Finland revealed the early eruption of teeth in rural northeastern Finland compared to that of the rest of the country (4).

An another study conducted among 1,370 Czech children showed that there were no significant differences observed in the eruption time between the right and left side of the jaw, and also revealed that the lower jaw teeth erupt earlier than the upper jaw, except premolars (12).

A study involving 4,370 students from 102 schools using systematic random sampling procedure in Karachi showed that, on average, the first erupted tooth was the right maxillary first molar, erupted at the age of 6.5 years and the last tooth was the mandible second molar, erupted at the age of 11.8 years. No gender difference was observed for eruption pattern in the study populations, and they concluded that the eruption time of Pakistani children differs from other nationalities (13).

The results of the study done on 890 children between the age of 5 to 15 in Ankara (Turkey) showed that the sequences of the eruption of permanent teeth were 6-1-2-4-3-5-7 in the mandible, and 6-1-2-4-5-3-7 in the maxilla in boys, whereas in girls the sequence was 1-6-2-3-4-5-7 in the mandible and 6-1-2-5-4-3-7 in the maxilla. The study indicated that sequences of eruption times show similarities, but there are some differences in premolars and canines. The authors considered that these eruption patterns are due to the early loss of primary molars (14).

The timing of eruption of permanent teeth has been studied among different ethnic groups and within the same ethnic group by earlier studies. A variation in the sequence of tooth eruption in both intra- and interethnic groups adds to difficulties in establishing the dental age. Tooth eruption time must be based upon a mean with wide latitude of variation for individual cases.

In this survey, we attempted to evaluate the mean age of eruption, the first permanent tooth to erupt and the sequence of eruption of permanent teeth in children aged between 5 and 10 years residing in Deralakatte, Mangalore.

In the present study, the first tooth to erupt was the left mandibular first molar with a mean age of eruption at 6.4 years and standard deviation of 0.614. Similar observations were noted in other studies done on Indian population, namely in Arunachal Pradesh (15), Karnataka (10, 11, 16), and Hyderabad (17). Studies on the eruption of permanent teeth in African population also reported a similar observation (6). However, this was not universal, as studies on eruption timings in Europe (Czech (12), Finland (4), Turkey (14)) and Iran (3) reported that the mandibular central incisor was the first permanent tooth to erupt. The above-mentioned differences in eruption timing between different populations of the world necessitate populationbased estimation of the eruption timing of teeth.

The most common polymorphism seen in the upper and lower teeth emergence sequence was the eruption of P2-C instead of C-P2 and I1-M1 instead of M1-I1, respectively. Smith and Garn analyzed the eruption polymorphisms by preparing matrices of the eruption sequence. They found the P1-C-P2 and M1-I1 sequence to be the most common polymorphism in the maxillary and mandibular arches (18). Accordingly, the sequence of eruption estimated in the present study was M1 CI LI for the maxilla and (M1 CI) LI C P1 for the mandible. A slight variation in the sequence other than mandibular canine (M1 CI) was noticed in the present study, whereas following the eruption of the right mandibular canine, the mandibular first premolars erupted before the eruption of the left mandibular canine. In the maxillary arch, there was a slight delay in the eruption of lateral incisors when compared to the standard age of eruption of lateral incisors.

The eruption timing of the permanent teeth on the left side of the jaw was compared to those of the right side in the present study. A slight early eruption of the teeth was found on the left side of the mouth, except for the mandibular canines. The variations, however, were not statistically significant.

\section{CONCLUSION}

The following conclusions were drawn from the present study: 
1) In the study population, the left mandibular first molar was the first permanent tooth to erupt in the oral cavity.

2) There was a slight delay in the eruption of the maxillary lateral incisor in the study population, when compared to those in the standard textbooks.

3) Polymorphism in the sequence of the eruption was noted in the mandibular teeth, where

a. first molars erupted before the central incisors

b. first premolars erupted before the left canine.

\section{Acknowledgement}

The authors thank all the contributors, including the staff at the Department of Pedodontics A. B. Shetty Memorial Institute of Dental Sciences Mangalore whose help and participation made this work possible.

\section{Conflict of Interest NIL}

We declare that none of the authors has financial disclosures and conflicts of interest.

\section{References}

1. Ash MM, Nelson SJ. Development and eruption of teeth. In: Dental Anatomy, Physiology and Occlusion. 8th Edition. St. Louis: Elsevier, 2003:49-51.

2. Gupta A, Hiremath SS, Singh SK, et al. Emergence of primary teeth in children of Sunsari district of Eastern Nepal. McGill J Med 2007; 10:11-5.

3. Moslemi M: An epidemiological survey of the time and sequence of eruption of permanent teeth in 4-15-year-olds in Tehran. Iran Int J Paediatr Dent 2004; 14: 432-8. https://doi.org/10.1111/i.1365-263X.2004.00586.x

4. Pahkala R, Pahkala A, Laine T. Eruption pattern of permanent teeth in a rural community in northeastern Finland. Acta Odontol Scand 1991; 49(6):341-9.

https://doi.org/10.3109/00016359109005930
5. Koch G, Poulsen S. Paediatric Dentistry - A clinical approach. Copenhagen: Munksgaard, 2001:40-6.

6. Billewicz WZ, McGregor IA. Eruption of permanent teeth in West African (Gambian) children in relation to age, sex and physique. Ann Human Biol 1975; 2: 117- 28. https://doi.org/10.1080/03014467500000661

7. Triratana T, Hemindra, Kiatiparjuk C. Eruption of permanent teeth in malnourished children. J Dent Assoc Thai 1990; 40: 100-8.

8. Stewart R, Thomas K, Troutman Kenneth C, Stephen HW. Pediatric Dentistry: Scientific Foundations and Clinical Practice. St Louis, MO: CV Mosby, 1982.

9. Bhaskar, S N, and Balint J. Orban. Orban's Oral Histology and Embryology. Elsevier India Private Limited.9th edition. 2015:281-94 
10. Lakshmappa A, Guledgud MV, Patil K. Eruption times and patterns of permanent teeth of school children in India. Indian J Dent Res 2011; 22: 755-63. https://doi.org/10.4103/0970-9290.94568

11. Kamei C, Limbu DK. The eruption of Permanent Teeth among the Gowda Girls of Kodagahalli Village of Mysore District of Karnataka. The Anthropologist 2013; 16(3): 731-4. https://doi.org/10.1080/09720073.2013.11891400

12. Šindelárová R, Žáková L, Broukal Z. Standards for permanent tooth emergence in Czech children. BMC Oral Health 2017;17(1):1-9. https://doi.org/10.1186/s12903-017-0427-9

13. Khan N. Eruption time of permanent teeth in Pakistani children. Iranian J Publ Health. 2011, 40: 63-73.

14. Oznurhana F, Ekci ES et al. Time and sequence of eruption of permanent teeth in Ankara, Turkey. Ped Dent J 2015; 26(1):1-7. https://doi.org/10.1016/j.pdj.2015.09.002

15. Limbu D.K., Khongsai L, Syiemlieh S. Eruption of Permanent Teeth among the Deori Boys of Mahadevpur Deori Village of Arunachal Pradesh, India. Imperial J Interdisciplin Res 2016; 2(4): 157-9.

16. Natarajan $S$, Chowdappa $S$, Yellapurkar $S$, at al. Permanent tooth emergence patterns in Dakshina Kannada region, India: an analysis of polymorphisms. Egypt J Forensic Sci 2018; 8:1-8. https://doi.org/10.1186/s41935-018-0104-4

17. Shahid H, Hassan S, Shaikh AA. Eruption of permanent teeth; assessment of eruption of permanent teeth according to gender in local population. Professional Med J 2018; 25(11):1741-6. https://doi.org/10.29309/TPMJ/18.4633

18. Smith BH, Garn SM. Polymorphisms in eruption sequence of permanent teeth in American children. Am J Phys Anthropol 1987; 74:289-303. https://doi.org/10.1002/ajpa.1330740303 


\title{
Studija o nicanju trajnih zuba kod dece uzrasta od pet do deset godina koja su posetila Stomatološki fakultet u gradu Mangalore $u$ Indiji
}

\author{
Varshini Marimuthu, Pushparaja Shetty \\ Departman za oralnu patologiju, Memorijalni institut za stomatološke nauke A.B. Shetty, \\ Univerzitet Nitte Deralakatte, Mangalore, Indija
}

\section{S AŽETAK}

Zubi su biološki markeri zrelosti i nicanje zuba u usnoj šupljini predstavlja značajan događaj u životu svake osobe. Veliki broj faktora igra ulogu u obrascu nicanja zuba, uključujući zubni karijes, uticaj fluorida, kao i urođena stanja, poput Daunovog sindroma.

Cilj rada bilo je određivanje vremena nicanja stalnih zuba kod dece uzrasta od pet do deset godina, koja su posetila Stomatološki fakultet u gradu Mangalore.

Studija je uključila ispitivanje dece uzrasta od pet do deset godina, koja su posetila Memorijalni institut za stomatološke nauke A.B. Shetty, Deralakatte, Mangalore. Kod svakog deteta, koje je učestvovalo u studiji, utvrđen je broj izniklih zuba i trajnih zuba u nicanju. Roditelji/staratelji su intervjuisani i njihovi odgovori su zabeleženi $i$ analizirani.

Studija je pokazala da prvo niče prvi kutnjak levo u mandibuli, dok je prosečna starost dece u kojoj se javlja nicanje prvog zuba iznosila 6,4 godine. U ovoj studiji uočeno je nešto ranije nicanje zuba na levoj strani vilice.

Prvi trajni zub koji je nikao u vilici bio je prvi kutnjak u mandibuli levo i primećeno je blago kašnjenje u nicanju maksilarnih lateralnih sekutića.

Ključne reči: nicanje, stalni zubi, denticija 